\title{
Condylomata acuminata and Candida vulvovaginitis during pregnancy - current facts and therapeutic possibilities
}

\author{
Verucile genitale şi vulvovaginita candidozică în timpul sarcinii - actualităţi \\ şi posibilităţi terapeutice
}
Ana Maria Alexandra Stănescu', Ioana Veronica Grăjdeanu', Mihaela Adela Iancu', Constantin Ştefani', Bogdan Şerban ${ }^{1}$, Ovidiu Gabriel Bratu ${ }^{1,2}$, Bogdan Socea ${ }^{1,3}$, Camelia Cristina Diaconu ${ }^{1,4}$

\author{
${ }^{1}$ Universitatea de Medicină şi Farmacie „Carol Davila“, Bucureşti, România \\ ${ }^{2}$ Spitalul Universitar de Urgenţă Militar Central „Dr. Carol Davila“, Bucureşti \\ ${ }^{3}$ Spitalul Clinic de Urgenţă „Sf. Pantelimon“, Bucureşti, România \\ ${ }^{4}$ Spitalul Clinic de Urgenţă, Bucureşti, România
}

\begin{abstract}
Condylomata acuminata during pregnancy represents genital, perineal and perianal hyperplasia as a result of infection with human papillomavirus during pregnancy. Candida vulvovaginitis is a symptomatic vaginitis (inflammation of the vagina and / or vulva) caused by Candida infection, with $10 \%$ of women being asympto-matic. These diseases present some particularities and therapeutical problems during pregnancy.

Keywords: Condylomata acuminata, Candida vulvovaginitis, pregnancy

\section{REZUMAT}

Condylomata acuminata în timpul sarcinii reprezintă hiperplazia genitală, perineală şi perianală, ca urmare a infectării cu papilomavirus uman în timpul sarcinii. Vulvovaginita candidozică este o vaginită simptomatică (inflamaţia vaginului şi/ sau a vulvei) cauzată de infecţia cu Candida, 10\% dintre femei putând avea forma asimptomatică. Aceste afecţiuni prezintă unele particularităţi şi probleme terapeutice în cazul gravidei.
\end{abstract}

Cuvinte cheie: Condylomata acuminata, vulvovaginita candidozică, sarcină

\section{INTRODUCERE}

Afecţiunile infecţioase în timpul sarcinii reprezintă o provocare atât pentru medici, cât şi pentru paciente. Unele infecţii pot avea repercusiuni atât asupra mamei, cât şi asupra fătului, putând provoca malformaţii congenitale. Abordarea poate fi dificilă din punctul de vedere al tratamentului, din cauza riscurilor la care sunt expuse atât mama, cât şi fătul. În aceste cazuri, se evidenţiază lipsa studiilor controlate în timpul sarcinii, fiind dificil de administrat tratament doar pe baza studiilor efectuate pe animale şi a experienţei clinice.
Infecţia cu HPV este cea mai răspândită boală venerică din lume. Mai mult de 200 de tipuri de HPV au fost identificate şi grupate ca având risc crescut sau scăzut oncogenic, dintre acestea peste 40 de tipuri de HPV pot fi transmise sexual (1). Verucile genitale se pot manifesta ca papule moi sau plăci pe organele genitale externe, pe tegumentul perianal, perineu, putând implica şi canalul anal, cervixul, vulva şi uretra, având o rată mare de recurenţă (2).

Candida albicans este un microorganism oportunist care colonizează mucoasa vaginală estrogenizată (3). O mare parte a femeilor vor dezvolta 
simptome vulvo-vaginale de candidoză cel puţin o dată în viaţă, iar la 1 din 10 femei va apare recurent (mai mult de 3 episoade simptomatice pe an) (3). Recurenţa afectează calitatea vieţii prin impactul fizic, social, psihic, dar şi economic asupra pacientelor (4).

De multe ori dificil de tratat şi rezistente la tratament, aceste infecţii creează reale probleme în ceea ce priveşte tratamentul lor la femeile gravide. Acest review este menit să identifice posibilităţile terapeutice actuale (inclusiv în cazurile care nu răspund la tratamentul de primă intenţie) la gravide.

\section{Condylomata acuminata (veruci genitale)}

Verucile genitale sunt manifestări comune genitale ale infecţiei cu papilomavirus uman (HPV) (5). În verucile genitale au fost izolate mai multe tipuri ale infecţiei cu papilomavirus uman, cum ar fi: HPV 2, 6, 11, 40, 42, 43, 54; dintre toate acestea, cel mai des asociate sunt HPV6 şi HPV11 (6). În Europa, prevalenţa infecţiei cu HPV este în creştere, ca şi incidenţa verucilor genitale. În Anglia şi Australia, o dată cu creşterea ratei de vaccinare, s-a raportat scăderea cazurilor de veruci genitale la femeile tinere $(7,8)$. Verucile genitale pot reprezenta o povară din punct de vedere economic, în SUA în 2004 s-au cheltuit peste 220 milioane dolari din cauza acestei afecţiuni, iar în Spania peste 64 milioane de dolari $(9,10)$.

Verucile genitale au efect negativ asupra calităţii vieţii, sunt refractare la tratament, se pot regenera spontan sau pot rămâne în remisie un timp îndelungat (11). De obicei sunt asimptomatice, mai puţin verucile vulgare, ce pot crea disconfort, prurit, sângerări, obstrucţii ale canalului de naştere şi infecţii neonatale care pot conduce la apariţia de papilomatoze recidivante juvenile (12). Vaccinarea cu vaccinul HPV cvadrivalent şi nonavalent, care oferă protecţie împotriva HPV 6 şi 11, poate reduce incidenţa verucilor genitale (13).

Condylomata acuminata în timpul sarcinii se referă la hiperplazia genitală, perineală şi perianală, ca urmare a infectării cu papilomavirus uman în timpul sarcinii (14). În special între săptămânile 12 şi 14 de gestaţie, verucile genitale pot să crească mai rapid şi să ajungă la o dimensiune foarte mare în comparaţie cu femeile care nu sunt gravide, HPV fiind reprodus activ din cauza modificării estrogenului şi mediului umed local $(15,16)$.

Aceste modificări specifice în timpul sarcinii se datorează scăderii imunităţii mediate celular şi creşterii vascularităţii tractului genital, fiind asociate o activare şi o viremie crescută a agentului cau- zal. Verucile care apar în timpul sarcinii se găsesc, în general, la nivelul orificiului vaginal, cervix şi pe peretele vaginal, fiind dificil de tratat din cauza riscului de ulcerare şi de infecţie (17). De asemenea, un alt impediment în tratament este reprezentat de restricţia administrării anumitor medicamente la gravidă.

În unele cazuri, verucile genitale pot ajunge la dimensiuni mari, încât pot duce la obstrucţia sau disfuncţia canalului de naştere, fiind recomandată operaţia cezariană pentru a evita hemoragia (16). Până în prezent, nu există date clare care să demonstreze că o femeie însărcinată infectată cu Condylomata acuminata poate transmite HPV către făt prin sânge; cu toate acestea, majoritatea fetuşilor afectaţi sunt direct infectaţi cu HPV prin canalul de naştere, iar aceşti sugari sunt susceptibili de a suferi de papilom laringian (18). HPV se poate transmite de la mamă la copil în timpul naşterii, putând să apară leziuni neonatale anogenitale, orale sau conjunctivale (19). Operaţia cezariană trebuie luată în considerare în cazul obstrucţiei canalului de naştere, în cazul ruperii precoce a membranelor sau atunci când se presupune o încărcare virală mare. Studiile epidemiologice nu au putut demonstra o protecţie a fătului pentru papilomatoza laringiană juvenilă în cazul operaţiei cezariene (20).

Metodele de tratament preferate în timpul sarcinii sunt reprezentate de terapiile chirurgicale, care cuprind: electrocauterizarea, excizie tangenţială cu o pereche de foarfece fine sau un scalpel, crioterapie (considerată terapie de primă linie) şi chirurgie laser $\mathrm{cu} \mathrm{CO}_{2}$. În ceea ce priveşte metodele nonchirurgicale, deşi mai puţin eficace, se poate aplica pe zone mici acid tricloroacetic (21).

În ceea ce priveşte terapiile topice care nu se pot utiliza la gravidă, avem: podofilotoxină - un compus activ din răşina podofillum (categoria $\mathrm{X}$ ), un medicament antimitotic, toxic pentru mamă, dar şi teratogen (malformaţii ale urechii, inimii şi extremităţilor) $(22,23,24)$. Alte terapii topice, cum ar fi cremă imiquimod $5 \%$ (de 3 ori pe săptămână pentru maximum 16 săptămâni), sunt absorbite sistemic în cantităţi mici; un studiu in vitro a sugerat că acesta nu modifică funcţia placentară normală (studiile pe gravide sunt limitate, însă nu au fost prezentate rezultate negative ale sarcinii), cu toate acestea, trebuie evitat în timpul sarcinii $(24,25)$. Sinecatecine unguent $10 \%$ (de 3 ori pe zi timp de maxim 16 săptămâni) nu are cunoscută siguranţa administrării în timpul sarcinii şi de aceea nu trebuie utilizat $(22,26)$. 


\section{Candida vulvovaginitis}

Candida vulvovaginitis apare mai frecvent în cazul terapiei cu antibiotice sau cu corticosteroizi, utilizarea contraceptivelor orale, diabetului, obezităţii, infecţiei cu HIV şi la femeile însărcinate (27). În ceea ce priveşte perioada sarcinii, până la $50 \%$ dintre gravide sunt afectate, sarcina fiind unul dintre factorii predispozanţi (27). Mecanismul se datorează valorii pH-ului mai scăzută la nivel vaginal, conţinutului crescut de glicogen, dar şi suprimarea bacteriilor rezidente care au rol de protecţie; toate acestea determină creşterea fungilor (21).

Cele mai multe cazuri de Candida vulvovaginitis, $85-90 \%$, sunt datorate Candida albicans, însă, în ultimul timp, apar tot mai frecvent şi Candida tropicalis, Candida glabrata şi Candida parapsilosis $(27,28)$. În timpul sarcinii, simptomatologia candidozei este mai severă în al III-lea trimestru de sarcină, în timp ce la începutul sarcinii simptomatologia poate lipsi. Prematuritatea şi greutatea mică la naştere se asociază cu colonizarea vaginală asimptomatică recurentă cu Candida la începutul sarcinii $(29,30)$.

Se poate transmite în timpul naşterii în momentul trecerii prin canalul de naştere infectat, Candida albicans găsindu-se la 50\% dintre nou-născuţii ce provin din mame infectate $(31,32)$. Nou-născuţii au de obicei afectare cutanată şi mucoasă, putându-se complica la cei imunosupresaţi şi în cazul greutăţii mici la naştere; în schimb, candidoza congenitală se prezintă cu leziuni cutanate generalizate, pneumonie şi chiar sepsis la scurt timp după naştere $(33,34)$.

TABELUL 1. Influentele candidozei în functie de trimestrul sarcinii (la 1.066 de paciente) (35)

\begin{tabular}{|l|c|c|}
\hline Parametri & $\begin{array}{c}\text { Trimestrul I } \\
\text { (Medie } \pm \text { DS, \%) }\end{array}$ & $\begin{array}{c}\text { Trimestrul II } \\
\text { (Medie } \pm \text { DS, \%) }\end{array}$ \\
\hline Naștere prematură & $10 \%$ & $18 \%$ \\
\hline $\begin{array}{l}\text { Vârsta gestațională la } \\
\text { naștere }\end{array}$ & $\begin{array}{c}38,9 \pm 2,3 \\
\text { (săptămâni) }\end{array}$ & $\begin{array}{c}37,8 \pm 3,9 \\
\text { (săptămâni) }\end{array}$ \\
\hline Scor Apgar la 1 minut & $8,7 \pm 1,0$ & $8,4 \pm 1,6$ \\
\hline Scor Apgar la 10 minute & $9,8 \pm 1,1$ & $9,6 \pm 1,6$ \\
\hline Greutate la naștere & $\begin{array}{c}3.234 \pm 600 \\
\text { (grame) }\end{array}$ & $\begin{array}{c}2.989 \pm 810 \\
\text { (grame) }\end{array}$ \\
\hline
\end{tabular}

Din perspectiva tratamentului vulvovaginitei cu Candida în timpul sarcinii, agenţii antifungici to- pici au o rată de vindecare de $80-90 \%$ în cazul infecţiei cu Candida albicans, mai ales în cazul tratamentului efectuat timp de 1-2 săptămâni (recurenţele fiind mai frecvente în timpul sarcinii) $(27,36)$.

Se poate spune că, din cauza utilizării îndelungate în practica medicală, clotrimazolul (1\% cremă, 100 mg sau 200 mg supozitoare) are o absorbţie vaginală şi cutanată minimă fără a produce defecte congenitale; mai nou, se consideră că poate împiedica naşterea prematură în cazul candidozei asimptomatice (37). Nistatin (cremă, comprimate vaginale 100.000 unităţi) nu prezintă o experienţă îndelungată în ceea ce priveşte utilizarea în timpul sarcinii şi nu există dovezi în ceea ce priveşte toxicitatea fetală $(38,39)$.

În cazurile speciale în care există rezistenţă la antifungice, se poate administra amfotericină B (administrare vaginală). Fluconazolul (administrat oral $150 \mathrm{mg} /$ zi timp de 7-14 zile) nu prezintă risc de malformaţii congenitale, naştere prematură, avort spontan sau greutate mică la naştere; cu toate acestea, ar trebui utilizat doar în cazul infecţiilor primare severe (40). O problemă ar putea fi reprezentată în cazul administrării dozelor mari de fluconazol (400-800 mg/zi), fiind cazuri în literatura de specialitate care au raportat defecte congenitale în urma administrării dozelor mari (41).

Itraconazolul oral (200-400 mg o dată sau 200 $\mathrm{mg} /$ zi timp de 2-7 zile) reprezintă o altă alternativă, cu condiţia administrării de scurtă durată; dovezile de teratogenitate lipsesc în cazul său (42).

\section{CONCLUZII}

Atât verucile genitale, cât şi vulvovaginita candidozică reprezintă o problemă, mai ales atunci când apar la gravidă. Pe de-o parte, dacă nu sunt tratate, fătul (nou-născutul) este expus, pe de altă parte, tratamentul ridică şi el problema afectării fătului. Decizia medicului asupra tratamentului este luată, cel mai probabil, în urma experienţei şi a altor cazuri clinice raportate. Lipsesc studiile clinice elocvente cu privire la tratamentul verucilor genitale şi al vulvovaginitei candidozice în timpul sarcinii.

instillations in two immunocompromised patients and review of the literature. Antiviral Research. 2018;158:238-243.

3. Sobel JD. Recurrent vulvovaginal candidiasis. Am J Obstet Gynecol 2016;214(1):15-21.

\section{BIBLIOGRAFIE}

1. De Villiers EM, Fauquet $C$, Broker TR et al. Classification of papillomaviruses. Virology 2004;324:17.

2. Florin HJ, Snoeck R, Van Cleynenbreugel B et al. Treatment of intraurethral Condylomata acuminata with surgery and cidofovir 
4. Aballéa S, Guelfucci F, Wagner J et al. Subjective health status and health-related quality of life among women with recurrent vulvovaginal candidosis (RVVC) in Europe and the USA. Health Qual Life Outcomes 2013;11:169.

5. Fenton KA, Lowndes CM. Recent trends in the epidemiology of sexually transmitted infections in the European Union. Sex Transm Infect. 2004;80(4):255-63.

6. Doorbar J, Egawa N, Griffin H, Kranjec C, Murakami I. Human papillomavirus molecular biology and disease association. Rev Med Virol. 2015;25(Suppl 1):2-23.

7. Patel H, Wagner M, Singhal P, Kothari S. Systematic review of the incidence and prevalence of genital warts. BMC Infect Dis. 2013;13:39.

8. Smith MA, Liu B, McIntyre P, Menzies R, Dey A, Canfell K. Fall in genital warts diagnoses in the general and indigenous Australian population following implementation of a national human papillomavirus vaccination program: analysis of routinely collected national hospital data. J Infect Dis. 2015;211(1):91-9.

9. Insinga RP, Dasbach EJ, Elbasha EH. Assessing the annual economic burden of preventing and treating anogenital human papillomavirusrelated disease in the US: analytic framework and review of the literature. PharmacoEconomics. 2005;23(11):1107-22.

10. Castellsague X, Cohet C, Puig-Tintore LM, Acebes LO, Salinas J, San Martin M, Breitscheidel L, Remy V. Epidemiology and cost of treatment of genital warts in Spain. Eur J Pub Health. 2009; 19(1):106-10.

11. Jeynes C, Chung MC. Challenor R. "Shame on you" - the psychosocial impact of genital warts. Int J STD AIDS. 2009;20(8):557-60.

12. Lynde $C$, Vender R, Bourcier M, Bhatia N. Clinical features of external genital warts. J Cutan Med Surg. 2013;17(Suppl 2):S55-60.

13. Villa LL, Costa RL, Petta CA, Andrade RP, Ault KA, Giuliano AR, Wheeler CM, Koutsky LA, Malm C, Lehtinen M et al. Prophylactic quadrivalent human papillomavirus (types 6, 11, 16, and 18) L1 virus-like particle vaccine in young women: a randomised double-blind placebo-controlled multicentre phase II efficacy trial. Lancet Oncol. 2005;6(5):271-8.

14. Arima $Y$, Winer RL, Feng $Q$ et al. Development of genital warts after incident detection of human papillomavirus infection in young men. J. Infect. Dis 2010;202:1181-1184.

15. Peter SA, Ha HD, George WR. Human papillomavirus in women. A three year experience in a country hospital colposcopy clinic. Pepord Med 1992;37:167.

16. Workowski KA, Bolan GA. Sexually transmitted diseases treatment guidelines, 2015. MMWR Recomm Rep 2015;64:1-137.

17. Jablonska $S$. Traditional therapies for the treatment of condylomata acuminata (genital warts). Australas. J. Dermatol 1998;39:S2-S4.

18. Ulla H, Astrid KNI, Anne S et al. Preralence of HPV types 11, 16 and 18 in cervical swabs. A study of 1362 pregnancy women. Fur. Obstet. Gynecol. Repord. Biol 1992;35:191.

19. Mant C, Cason J, Rice P. Non-sexual transmission of cervical cancer-associated papillomaviruses: An update. Papillomavirus Rep 2000;11:1-5

20. Silverberg MJ, Thorsen $\mathrm{P}$, Lindeberg $\mathrm{H}$ et al. Condyloma in pregnancy is strongly predictive of juvenile-onset recurrent respiratory papillomatosis. Obstet Gynecol 2003;101:645-652.

21. Khan F, Mays R, Brooks J. Viral and sexually transmitted disease. G. Kroumpouzos (Ed.), Text Atlas of Obstetric Dermatology, Lippincott Williams \& Wilkins, Philadelphia 2013;PA:126-140.

22. Tatti S, Stockfleth E, Beutner KR et al. Polyphenon E: A new treatment for external anogenital warts. Br J Dermatol 2010;162:176-184.
23. Kirtschig G, Schaefer C. Wart therapeutics. C. Schaefer, P. Peters, R. Miller (Eds.), Drugs During Pregnancy and Lactation: Treatment Options and Risk Assessment (3rd ed.), Academic Press, Waltham, MA (2014), p. 480.

24. Karol MD, Conner CS, Watanabe AS et al. Podophyllum: Suspected teratogenicity from topical application. Clin Toxicol 1980;16:283-286.

25. Briggs G, Freeman R, Yaffe S. Drugs in Pregnancy and Lactation (9th ed.), Lippincott Williams \& Wilkins, Philadelphia, PA (2011).

26. Einarson A, Costei A, Kalra $S$ et al. The use of topical $5 \%$ imiquimod during pregnancy: A case series. Reprod Toxicol 2006;21:1-2.

27. Sobel J. Vulvovaginal candidiasis. K. Holmes, P. Mardy, P. Sparling (Eds.), Sexually Transmitted Diseases (4th ed.), MacGraw Hill, New York, NY (2008), pp. 823-838.

28. Aguin TJ, Sobel JD. Vulvovaginal candidiasis in pregnancy. Curr Infect Dis Rep 2015;17:462.

29. Farr A, Kiss H, Holzer I et al. Effect of asymptomatic vaginal colonization with Candida albicans on pregnancy outcome. Acta Obstet Gynecol Scand 2015;94:989-996.

30. Stănescu AMA, Grăjdeanu IV, Codreanu IF et al. Dermatological emergencies in neonatology and pediatric practice. Romanian Journal of Maternal-Fetal and Neonatal Medicine 2018;II(2):80-83.

31. Greenberg RG, Benjamin Jr DK. Neonatal candidiasis: Diagnosis, prevention, and treatment. J Infect 2014;69(Suppl. 1):S19-S22.

32. Stănescu AMA, Stefani C, Grăjdeanu IV et al. The complex implications of dermatoses specifically associated with pregnancy. Romanian Journal of Military Medicine 2019;CXXII(1):85-90.

33. Skoczylas MM, Walat A, Kordek A et al. Congenital candidiasis as a subject of research in medicine and human ecology. Ann Parasitol 2014;60:179-189.

34. Stănescu AMA, Grăjdeanu IV, Codreanu IF et al. Pregnancy associated with psoriasis - adverse outcomes and treatment. Romanian Journal of Maternal-Fetal and Neonatal Medicine 2018; II(2):64-67.

35. Holzer I, Farr A, Kiss $\mathrm{H}$ et al. The colonization with Candida species is more harmful in the second trimester of pregnancy. Arch Gynecol Obstet. 2017;295(4):891-895.

36. Grajdeanu IV, Stănescu AMA, Stefani $C$ et al. Impactul asupra mamei, fătului şi nou-născutului în cazul varicelei la gravidă. Practica Medicală 2019; 14,1(64):21-25.

37. Roberts CL, Algert CS, Rickard KL et al. Treatment of vaginal candidiasis for the prevention of preterm birth: A systematic review and meta-analysis. Syst Rev 2015;4:31.

38. Czeizel AE, Kazy Z, Puho E. A population-based case-control teratological study of oral nystatin treatment during pregnancy. Scand J Infect Dis 2003;35:830-835.

39. Stefani C, Grajdeanu IV, Serban B et al. Importanţa cunoaşterii manifestărilor cutanate fiziologice în sarcină pentru managementul corect al afecţiunilor cutanate în sarcină. Practica Medicală 2019; 14,1(64):26-29.

40. Alsaad AM, Kaplan YC, Koren G. Exposure to fluconazole and risk of congenital malformations in the offspring: A systematic review and meta-analysis. Reprod Toxicol 2015;52:78-82.

41. Lopez-Rangel E, Van Allen MI. Prenatal exposure to fluconazole: An identifiable dysmorphic phenotype. Birth Defects Res A Clin Mol Teratol 2005;73:919-923.

42. De Santis M, Di Gianantonio E, Cesari E et al. First-trimester itraconazole exposure and pregnancy outcome: A prospective cohort study of women contacting teratology information services in Italy. Drug Saf 2009;32:239-244. 